\title{
Inhibition of Cellular Respiration by 1,3,4-Thiadiazolo[3,2-a]pyrimidines ${ }^{\dagger}$
}

\author{
Masahito Suiko, Eiji TAniguchi, Kazuyuki MaEKaWA* \\ and Morifusa Eто \\ Department of Agricultural Chemistry, Kyushu University, \\ Fukuoka 812, Japan \\ Received October 23, 1978
}

\begin{abstract}
2-Ethylsulfonyl-7-methyl-5H-1, 3, 4-thiadiazolo[3, 2-a]pyrimidin-5-one ( $\left.\mathrm{TPSO}_{2}-2\right)$ showed inhibitory activity on cellular respiration of Ehrlich ascites tumor cells (E-cells) and Escherichia coli at $3.9 \times 10^{-4} \mathrm{M}$. In polarographic traces of rat liver mitochondrial respiration, the agent inhibited the energy transfer of oxidative phosphorylation at $8 \times 10^{-4} \mathrm{M}$. However, in the presence of tricine[ $N$-tris(hydroxymethyl)methylglycine], the $\mathrm{TPSO}_{2}-2$ inhibitory activity on cellular respiration disappeared. The permeability of cells was altered by $\mathrm{TPSO}_{2}-2$ treatment, and this effect was interrupted by adding tricine. $\mathrm{TPSO}_{2}-2$ did not inhibit the multiplication of $E$. coli in the presence of tricine but did inhibit E-cell multiplication. This means that the inhibitory activity of $\mathrm{TPSO}_{2}-2$ on $E$. coli multiplication is attributable to respiration inhibition, whereas the cytotoxicity of $\mathrm{TPSO}_{2}-2$ should be due to reasons other than respiration inhibition.
\end{abstract}

Some derivatives of 1,3,4-thiadiazolo[3,2-a]pyrimidine, a kind of purine analogs, were cytotoxic to Ehrlich ascites tumor cells (E-cells) and other experimental cells at growing phase. Strong activity was found among compounds which had an electrophilic substituent, such as alkylsulfinyl or alkylsulfonyl group at 2position. ${ }^{13}$

2-Ethylsulfonyl- 7 -methyl- $5 \mathrm{H}$-1, 3, 4-thiadiazolo[3,2-a]pyrimidin-5-one $\left(\mathrm{TPSO}_{2}-2\right)$, the most active compound in this series, scarcely inhibited DNA polymerase, protein synthesis system and DNA-dependent RNA polymerase obtained from Escherichia coli K-12, but strongly inhibited DNA-dependent RNA polymerase from E-cells. ${ }^{2)}$ However, $\mathrm{TPSO}_{2}-2$ suppressed the multiplication of both E-cells and $E$. coli. This suggests another mode of action of $\mathrm{TPSO}_{2}-2$, besides RNA polymerase inhibition.

\footnotetext{
${ }^{\dagger}$ Studies on Biologically Active Thiadiazolopyrimidines. Part III. See Ref. 2 for Part II.

* Present address: Fukuoka Junior College of Social Work and Nursery, Takawa-shi, Fukuoka 825.

Abbreviation: DNP, 2, 4-dinitrophenol; E-cells, Ehrlich ascites tumor cells; PBS $(-)$, phosphate buffered saline (without $\mathrm{Ca}^{2+}$ and $\mathrm{Mg}^{2+}$ ); $\mathrm{TPSO}_{2}-2$, 2-ethylsulfonyl-7-methyl- $5 H-1,3,4$-thiadiazolo [3, 2-a] pyrimidin-5-one; tricine, $N$-tris(hydroxymethyl)methylglycine.
}

In this paper the effects of $\mathrm{TPSO}_{2}-2$ as to respiration, permeability and glycolysis are examined. It acted as an inhibitor on energy transfer for mitochondrial oxidative phosphorylation. This appears to be the mode of action of $\mathrm{TPSO}_{2}-2$ for bactericidal activity but only a minor factor for cytotoxicity to E-cells.

\section{EXPERIMENTAL}

Materials. $\quad \mathrm{TPSO}_{2}-2$ was prepared as reported previously.1) ADP, ATP, phosphoenolpyruvate, pyruvate kinase, lactate dehydrogenase and other reagents were purchased from the Boehringer Mannheim Yamanouchi Co. E-cells were harvested from ddN female mice inoculated 5-7 days beforehand with $\mathrm{E}$ cells and washed with PBS $(-)$. The cultured E-cells were prepared, as reported previously. ${ }^{1)}$ E. coli $\mathrm{K}-12$ was grown by shaking in liquid medium of $\mathrm{pH} 7.0$ containing $0.5 \%$ glucose, $0.5 \%$ yeast extract and $2 \%$ peptone.

Cytotoxicity of $\mathrm{TPSO}_{2}-2$ on E-cells and $\mathrm{E}$. coli. The cytotoxicity of $\mathrm{TPSO}_{2}-2$ on cultured E-cells was estimated by the method described previously. ${ }^{1)}$ Ecells were incubated at $37^{\circ} \mathrm{C}$ for 3 days and counted by using the Bürkel Türk haematometer. The effect of $\mathrm{TPSO}_{2}-2$ on growth of $E$. coli was estimated spectrometrically at $610 \mathrm{~nm}$. Test tubes containing $6 \mathrm{ml}$ of the medium described above were inoculated with $10^{8}$ cells of $E$. coli and cultured at $30^{\circ} \mathrm{C}$ for $18 \mathrm{hr}$ by shaking at $115 \mathrm{rpm}$. 
Cellular respiration. Respiration of E-cells and $E$. coli was determined in a Warburg manometer at $37^{\circ} \mathrm{C}$. The center well of each vessel contained $0.2 \mathrm{ml}$ of $20 \%$ potassium hydroxide and a piece of filter paper. Each vessel contained $2.3 \mathrm{ml}$ of cell suspension and $0.5 \mathrm{ml}$ of $\mathrm{TPSO}_{2-2}$. A buffer solution was substituted for $\mathrm{TPSO}_{2}-2$ in controls. $\mathrm{TPSO}_{2}-2$ was added after a $20 \sim 30 \mathrm{~min}$ incubation and oxygen uptake was determined at $5 \sim 15 \mathrm{~min}$ intervals for $120 \mathrm{~min}$.

Preparation of mitochondria, Rat liver mitochondria was prepared according to Hogeboom's procedure $^{32}$ in medium containing $0.25 \mathrm{M}$ sucrose and $0.1 \mathrm{~mm}$ EDTA and adjusted to pH 7.4 with Tris-HCl. The final mitochondrial concentrations of respiratory and ATPase measurement systems were approximately 0.8 and $0.3 \mathrm{mg}$ of protein per $\mathrm{ml}$, respectively.

Mitochondrial respiration. Respiration of rat liver mitochondria was followed polarographically with a Clark oxygen electrode (Yellow-Springs Instrument Co.) at $37^{\circ} \mathrm{C}$ (volume, $3 \mathrm{ml}$ ). The medium consisted of sucrose $0.25 \mathrm{M}, \mathrm{KCl} 0.01 \mathrm{M}, \mathrm{K}_{2} \mathrm{HPO}_{4} 0.01 \mathrm{M}$, Tris$\mathrm{HCl} 0.01 \mathrm{M}, \mathrm{MgCl}_{2} 2 \mathrm{~mm}$ and EDTA $0.2 \mathrm{~mm}$ and was adjusted to $\mathrm{pH} 7.4 .{ }^{4}$

ATPase activity. The ATPase activity of liver mitochondria was assayed in the presence of an ATPregenerating system consisting of phosphoenolpyruvate and pyruvate kinase. ${ }^{s)}$ After the reaction was stopped with trichloroacetic acid at $10 \%$ final concentration, inorganic phosphate was determined in the supernatant according to Fiske and SubbaRow. ${ }^{\text {? }}$ ' Protein was determined according to Hartree.?

Cell permeability. This was determined by staining E-cells with nigrosine ${ }^{8, \theta)}$ or erythrosine $B{ }^{10}{ }^{10}$

Interaction of E-cells with $\mathrm{TPSO}_{2}-2 . \quad$ E-cells were boiled for $1 \mathrm{~min}$ and washed several times with PBS(-) or tricine buffer [tricine $50 \mathrm{~mm}, \mathrm{NaCl} 95 \mathrm{~mm}, \mathrm{KCl}$ $5 \mathrm{mM}, \mathrm{MgCl}_{2} 2 \mathrm{mM}, \mathrm{pH}$ 7.4].10) The cells and $\mathrm{TPSO}_{2}-2$ $\left(1.5 \times 10^{-4} \mathrm{M}\right)$ were incubated at $37^{\circ} \mathrm{C}$ for 1 or $2 \mathrm{hr}$, and centrifuged at $3,000 \mathrm{rpm}$ for $10 \mathrm{~min}$. Free $\mathrm{TPSO}_{2}-2$ in the supernatant was determined spectrometrically at $300 \mathrm{~nm}$.

Glycolysis. Glycolytic activity was measured in a final volume of $1 \mathrm{ml}$ according to McCoy's procedure. ${ }^{10)}$ E-cells ( $4 \mathrm{mg}$ protein: $8 \times 10^{\circ}$ cells) suspended in PBS( - ) were incubated at $37^{\circ} \mathrm{C}$ for $5 \mathrm{~min}$ by shaking. Reactions were started by addition of $10 \mathrm{~mm}$ of glucose. After $30 \mathrm{~min}$ at $37^{\circ} \mathrm{C}, 1 \mathrm{ml}$ of $10 \%$ trichloroacetic acid was added, and the mixture was centrifuged at $1,000 \times g$ for $10 \mathrm{~min}$. The supernatant was subjected to lactate assay, as described by Hohorst. ${ }^{11)}$

\section{RESULTS}

\section{Inhibition of respiration and the effect of tricine buffer}

In the manometric measurements, potassium cyanide and rotenone, well-known respiratory inhibitors, depressed the oxygen uptake of E-cells $\left(8 \times 10^{6}\right.$ cells) at $10^{-3} \mathrm{M}$ and $10^{-5} \mathrm{M}$, respectively. Similarly, $\mathrm{TPSO}_{2}-2$ in $\mathrm{PBS}(-)$ depressed almost completely the oxygen uptake of E-cells at a concentration of $3.9 \times 10^{-4} \mathrm{M}$, as shown in Fig. 1.

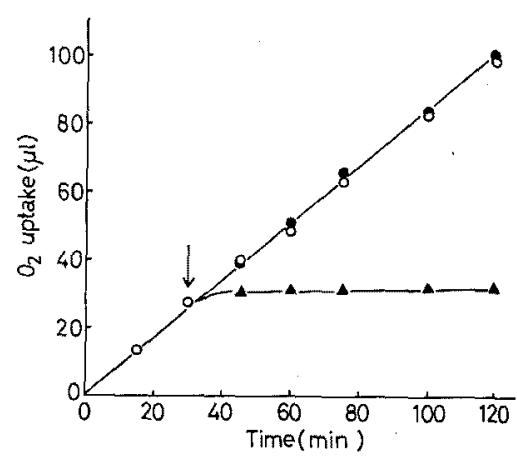

FIG. 1. Effect of $\mathrm{TPSO}_{2}-2$ on Respiration of E-Cells. $\bigcirc-\mathrm{O}$, Control $[\mathrm{PBS}(-)$ or tricine buffer]; $\mathrm{TPSO}_{2}-2$ in tricine buffer $\left(3.9 \times 10^{-4} \mathrm{M}\right) ;-\mathbf{\Lambda}$, $\mathrm{TPSO}_{2}-2$ in $\mathrm{PBS}(-)\left(3.9 \times 10^{-4} \mathrm{M}\right) ; \downarrow$, addition of test solution.

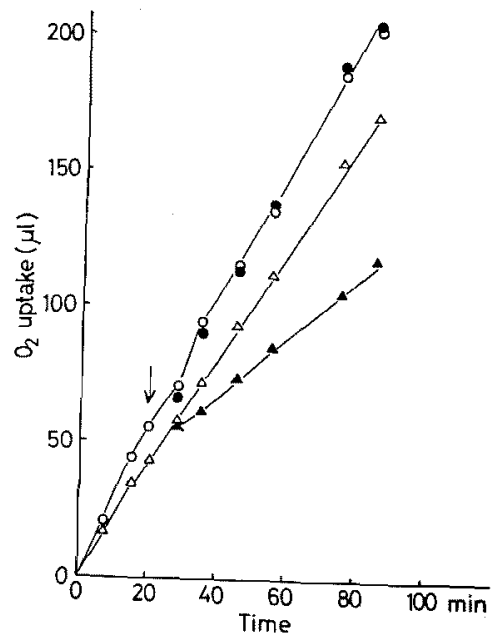

Fig. 2. Effect of $\mathrm{TPSO}_{2}-2$ on Respiration of $E$. coli. $\bigcirc-O$, Control (tricine buffer); $\triangle-\triangle$, control (PBS $(-))$; $-\bullet, \mathrm{TPSO}_{2}-2$ in tricine buffer $\left(3.9 \times 10^{-4} \mathrm{M}\right)$; $\Lambda-\Lambda$, TPSO $_{2}-2$ in PBS $(-)\left(3.9 \times 10^{-4} \mathrm{M}\right) ; \downarrow$, addition of test solution. 
Table I. Effect of Tricine Buffer on Cell Permeability of $\mathrm{TPSO}_{2}-2^{a}$

\begin{tabular}{|c|c|c|c|}
\hline $\begin{array}{l}\text { E-Cells washed } \\
\text { with }\end{array}$ & Pretreatment & $\begin{array}{c}\mathrm{TPSO}_{2}-2\left(3 \times 10^{-4} \mathrm{M}\right) \\
\text { dissolved in }\end{array}$ & $\begin{array}{c}\text { Rate of } \\
\text { nigrosine stain }(\%)\end{array}$ \\
\hline PBS (-) & - & PBS $(-)$ & 100 \\
\hline PBS (-) & - & Tricine buffer & 76 \\
\hline PBS (-) & Washed with tricine buffer & PBS (-) & 90 \\
\hline PBS (-) & $\begin{array}{l}\text { Added } 2 \text { drops of tricine } \\
\text { buffer and incubated for } \\
30 \mathrm{~min}\end{array}$ & PBS $(-)$ & 30 \\
\hline Tricine buffer & - & Tricine buffer & 0 \\
\hline Tricine buffer & - & PBS $(-)$ & 90 \\
\hline Tricine buffer & $\begin{array}{l}\text { Incubated for } 30 \mathrm{~min} \text { in } \\
\text { tricine buffer and washed } \\
\text { with PBS }(-)\end{array}$ & $\operatorname{PBS}(-)$ & 85 \\
\hline Tris-HCl buffer & - & Tris-HCl buffer & 100 \\
\hline
\end{tabular}

Against $E$. coli $\left(\mathrm{A}_{610}=11.6\right), \mathrm{TPSO}_{2}-2$ in PBS $(-)$ inhibited respiration less effectively at the same dose, but at a lower concentration respiration was not inhibited (Fig. 2).

However, when tricine buffer was used instead of PBS $(-)$, the $\mathrm{TPSO}_{2}-2$ inhibitory activity on respiration of E-cells and $E$. coli disappeared (Figs. 1 and 2). A factor in tricine buffer reponsible for extinguishing the $\mathrm{TPSO}_{2}-2$ inhibitory activity on respiration was concluded to be the tricine molecule itself.

When E-cells were pretreated with tricine, the $\mathrm{TPSO}_{2}-2$ inhibitory activity on cellular respiration disappeared. The same phenomenon was found on cell permeability of E-cells (Table I). TPSO $_{2}-2$ in PBS $(-)$ altered E-cell permeability, but when $\mathrm{TPSO}_{2}-2\left(3 \times 10^{-4} \mathrm{M}\right)$ in tricine buffer was added to E-cells which were washed with tricine buffer, the cells were not stained with nigrosine or erythrosine $\mathrm{B}$.

The cytotoxic activities and the effect of $\mathrm{TPSO}_{2}-2$ on respiration of E-cells and E. coli were tested in medium with and without tricine. The cultured E-cells were incubated for 3 days, while $E$. coli was cultured for $18 \mathrm{hr}$ with shaking. The results are shown in Tables II and III. The effect of $\mathrm{TPSO}_{2}-2$ on respiration of E-cells or $E$. coli was extremely distinct in the buffer used as mentioned above. The cytotoxicity of $\mathrm{TPSO}_{2}-2$ in $\mathrm{PBS}(-)$ on E-cells appeared in $2 \mathrm{hr}$ incubation, but that of $\mathrm{TPSO}_{2}-$
2 in tricine buffer did not entirely. When E-cells were cultured for 3 days, however, the cytotoxic activity of $\mathrm{TPSO}_{2}-2$ in tricine buffer on E-cells was the same as that in $\operatorname{PBS}(-)$, that is, $\mathrm{LC}_{50}$ was $3 \mu \mathrm{g} / \mathrm{ml}\left(1 \times 10^{-5} \mathrm{M}\right)$ in both the buffers (Table II). On the other hand, the inhibitory activity of $\mathrm{TPSO}_{2}-2(100 \mu \mathrm{g} / \mathrm{ml}$ : $3.8 \times 10^{-4} \mathrm{M}$ ) on $E$. coli multiplication was not

TAble II. Cytotoxicity and Efrect of $\mathrm{TPSO}_{2}-2$ ON ResPiration of E-CellLS

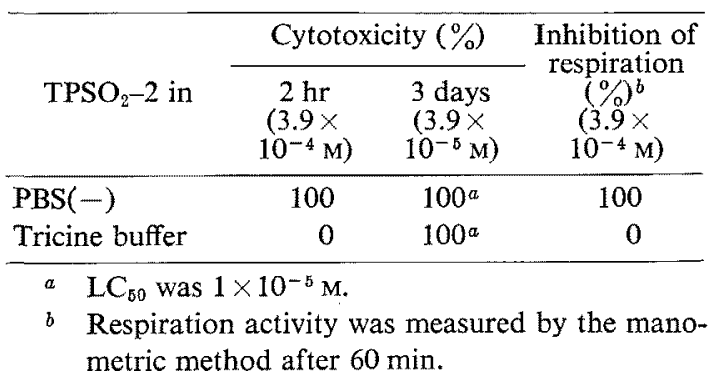

TABLE III. EFFeCt OF $\mathrm{TPSO}_{2}-2$ ON GROWTH AND RespiRATION OF E. coli

\begin{tabular}{|c|c|c|}
\hline $\mathrm{TPSO}_{2}-2$ in & $\begin{array}{l}\text { Inhibition of } \\
\text { growth }(\%)^{a} \\
\left(3.9 \times 10^{-4} \mathrm{M}\right)\end{array}$ & $\begin{array}{l}\text { Inhibition of } \\
\text { respiration }(\%)^{b} \\
\left(3.9 \times 10^{-4} \mathrm{M}\right)\end{array}$ \\
\hline $\operatorname{PBS}(-)$ & 100 & 53 \\
\hline Tricine buffer & 0 & 0 \\
\hline
\end{tabular}

a E. coli $\left(10^{8}\right.$ cells) were cultured for $18 \mathrm{hr}$ at $37^{\circ} \mathrm{C}$ with shaking. Growth inhibition was estimated from $A_{810}$.

$b$ Respiration activity was measured by the manometric method after $60 \mathrm{~min}$. 


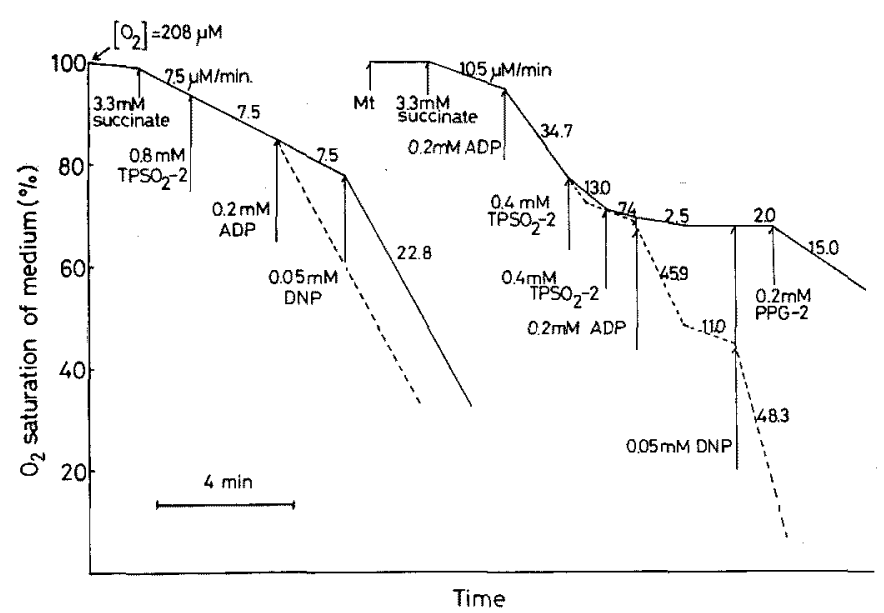

FIG. 4. Effect of $\mathrm{TPSO}_{2}-2$ on Oxygen Uptake of Rat Liver Mitochondria.

--.--, Without $\mathrm{TPSO}_{2}-2$; __, with $\mathrm{TPSO}_{2}-2$.

present in tricine buffer but was present in $\operatorname{PBS}(-)$.

\section{Interaction of E-cells with $\mathrm{TPSO}_{2}-2$}

The adsorption on E-cell membrane of $\mathrm{TPSO}_{2}-2$ in each buffer was measured. Cells killed by boiling were used to avoid interference of $\mathrm{TPSO}_{2}-2$ measurement at $300 \mathrm{~nm}$ with something released from living cells. As shown in Fig. 3, TPSO $_{2}-2$ adsorption on the surface of E-cells was inhibited by tricine molecules. The adsorbed $\mathrm{TPSO}_{2}-2$ in tricine buffer

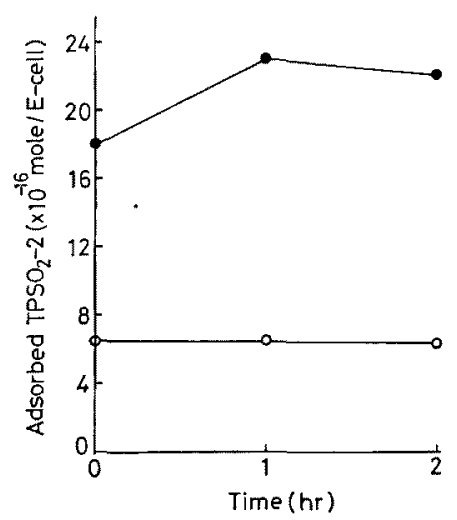

FIG. 3. Interaction of Dead E-Cells with $\mathrm{TPSO}_{2}-2$ in PBS $(-)$ or Tricine Buffer.

$\mathrm{TPSO}_{2}-2$ adsorbed on E-cell (mol/E-cell) was determined from ultraviolet absorption of free $\mathrm{TPSO}_{2}-2$ in supernatant at $300 \mathrm{~nm}$. - , in $\operatorname{PBS}(-) ; 0-0$, in tricine buffer. was one-third to one-fourth that in $\operatorname{PBS}(-)$. From this fact, tricine molecules appeared to inhibit the combining of $\mathrm{TPSO}_{2}-2$ molecules to the cell membrane.

Effect of $\mathrm{TPSO}_{2}-2$ on mitochondrial respiration The inhibitory action mode of $\mathrm{TPSO}_{2}-2$ on rat liver mitochondrial respiration was investigated. The results are illustrated with polarographic traces, shown in Fig. 4. When $\mathrm{TPSO}_{2}-$ $2\left(8 \times 10^{-4} \mathrm{M}\right)$ was added to the incubation mixture in state 4 oxidation of succinate, the addition of ADP $\left(2 \times 10^{-4} \mathrm{M}\right)$ did not increase the oxygen uptake rate. However, the addition of 2,4-dinitrophenol (DNP) $\left(5 \times 10^{-5} \mathrm{M}\right)$, an uncoupling agent, ${ }^{12}$ ) apparently increased the rate of oxidation. Next, $\mathrm{TPSO}_{2}-2(8 \times$ $10^{-4} \mathrm{M}$ ) added in state 3 oxidation, gradually depressed the rate of oxidation. Neither ADP nor DNP increased it, but 2-phenylpropylguanidino-4,6-dimethylpyrimidine (PPG-2) $\left(2.4 \times 10^{-4} \mathrm{M}\right)$, an uncoupling agent reported by Shuto et al., ${ }^{13)}$ increased the oxidation.

\section{Effect of TPSO ${ }_{2}-2$ on ATPase activity}

The effect of $\mathrm{TPSO}_{2}-2$ on ATPase of rat liver mitochondria is shown in Table IV. $\mathrm{TPSO}_{2}-2$ had no effect on ATPase activity itself, but inhibited DNP action on ATPase activity. This finding suggests that $\mathrm{TPSO}_{2}-2$ 
TABLE IV. EFFECT OF TPSO $_{2}-2$ ON RAT LIVER MITOCHONDRIAL ATPASE ${ }^{a}$

\begin{tabular}{lc}
\hline \multicolumn{1}{c}{ Additions } & $\begin{array}{c}\mu \mathrm{mol} \mathrm{Pi} / \mathrm{mg} \\
\text { protein } / \mathrm{min}\end{array}$ \\
\hline None & 0.34 \\
$+3.8 \times 10^{-4} \mathrm{M} \mathrm{TPSO}_{2}-2$ & 0.35 \\
$+1.2 \times 10^{-4} \mathrm{M} \mathrm{TPSO}_{2}-2$ & 0.33 \\
$+3.8 \times 10^{-5} \mathrm{M} \mathrm{TPSO}_{2}-2$ & 0.35 \\
$+5.0 \times 10^{-5} \mathrm{M} \mathrm{DNP}^{-2}$ & 0.49 \\
$+5.0 \times 10^{-3} \mathrm{M} \mathrm{DNP}+3.8 \times 10^{-4} \mathrm{M}$ & 0.39 \\
TPSO $_{2}-2$ & \\
\hline
\end{tabular}

a ATPase activity of rat liver mitochondria was determined at $37^{\circ} \mathrm{C}$ for $15 \mathrm{~min}$ using the Kagawa method. ${ }^{5)}$

TABLE V. EFFECT OF TPSO $_{2}-2$ ON Glycolysis of E-Cells

\begin{tabular}{lcc} 
Addition & $\begin{array}{c}\text { Lactate } \\
\text { formation } \\
(\mu \mathrm{mol} / \\
30 \mathrm{~min} / \mathrm{mg} \\
\text { protein })\end{array}$ & $\begin{array}{c}\text { Inhibition } \\
(-) \text { or } \\
\text { promotion } \\
(+)(\%)\end{array}$ \\
\hline $\begin{array}{c}\text { None } \\
+ \text { Dextran sulfate } \\
\left(2.7 \times 10^{-5} \mathrm{M}\right)\end{array}$ & 0.30 & -33.4 \\
$+\mathrm{DNP}$ & 0.20 & +20.0 \\
$\left(5.4 \times 10^{-4} \mathrm{M}\right)$ & 0.36 & 0 \\
$+\mathrm{TPSO}-2$ & 0.30 & \\
$\left(7.7 \times 10^{-4} \mathrm{M}\right)$ & & 0 \\
\hline
\end{tabular}

a E-cells $\left(8 \times 10^{8}\right.$ cells) were incubated with the indicated concentration of each compound for $30 \mathrm{~min}$ at $30^{\circ} \mathrm{C}$.

acts in a manner similar to that of oligomycine, the inhibitor of energy transfer of oxidative phosphorylation. ${ }^{14,15)}$

\section{Effect of $\mathrm{TPSO}_{2}-2$ on glycolysis}

The result shown in Table $\mathrm{V}$ indicates that glycolysis of E-cells is not inhibited even at such a high concentration of $\mathrm{TPSO}_{2}-2$ as $7.7 \times 10^{-4} \mathrm{M}$.

\section{DISCUSSION}

$\mathrm{TPSO}_{2}-2$ showed inhibitory activities on cellular and mitochondrial respiration at $3.9 \times$ $10^{-4} \mathrm{M}$ and $8 \times 10^{-4} \mathrm{M}$, respectively. Its mode of action was found to be inhibition of energy transfer of oxidative phosphorylation. However, in the presence of tricine the $\mathrm{TPSO}_{2}-2$ inhibitory activity on cellular respiration dis- appeared, and the alteration of cell permeability also disappeared. TPSO ${ }_{2}-2$ adsorption on the E-cell membrane decreased in the presence of tricine molecules. However, the effect of $\mathrm{TPSO}_{2}-2$ on rat liver mitochondrial respiration did not disappear by addition of tricine. Thus, it can be presumed that certain binding sites for $\mathrm{TPSO}_{2}-2$ may be present on the cell surface and that binding with TPSO $_{2}-2$ may be inhibited by the tricine molecules.

$\mathrm{TPSO}_{2}-2$ did not inhibit the multiplication of $E$. coli even in the presence of tricine molecules, but did inhibit E-cells and had no effect on glycolysis. Therefore, the inhibitory activity of $\mathrm{TPSO}_{2}-2$ on $E$. coli multiplication is attributable to respiration inhibition. On the other hand, for the inhibition of E-cell multiplication, another mechanism of action than respiratory inhibition could be responsible. As reported previously, ${ }^{2)}$ the inhibition of RNA synthesis can be thought as the most reasonable mode of action for cytotoxicity; $\mathrm{TPSO}_{2}-2$ inhibits RNA polymerase at a much lower concentration $\left(5 \times 10^{-5} \mathrm{M}\right)$ than respirations of cells $\left(4 \times 10^{-4} \mathrm{M}\right)$ or mitochondria $\left(8 \times 10^{-4} \mathrm{M}\right)$.

Acknowledgements. The authors thank Dr. Y. Shuto of this university for his helpful advice and discussion.

\section{REFERENCES}

1) M. Suiko and K. Maekawa, Agric. Biol. Chem., 41, 2047 (1977).

2) M. Suiko, E. Taniguchi, K. Maekawa and M. Eto, Agric. Biol. Chem., 43, 741 (1979).

3) G. H. Hogeboom, "Methods in Enzymology," Vol. 1, ed. by S. P. Colowick and N. O. Kaplan, Academic Press Inc., New York, N.Y., 1955, p. 16.

4) B. Hagihara, Protein, Nucleic Acid and Enzyme. 10, 1689 (1965).

5) K. Kagawa, "Methods in Membrane Biology," Vol. 1, ed. by E. Karn, Prenum Press, New York, N. Y., 1974, p. 201.

6) C. H. Fiske and Y. SubbaRow, J. Biol. Chem., 66, 375 (1925).

7) E. F. Hartree, Anal. Biochem., 48, 422 (1972).

8) J. P. Kaltenback, M. H. Kaltenback and W. B. Lyons, Exp. Cell Res., 15, 112 (1958).

9) M. Suiko and K. Maekawa, J. Fac. Agr., Kyushu Univ., 21, 91 (1977). 
10) G. D. McCoy R. C. Resch and E. Racker Cancer Res. 36, 3339 (1976).

11) H. J. Hohorst, "Methods of Enzymatic Analysis, ed. by H. U. Bergmer, Academic Press Inc., New York, N. Y., 1963, p. 266.

12) P. Vignais, Biochim. Biophys. Acta, 78, 404 (1963).
13) Y. Shuto, E. Taniguchi and M. Eto, Agric. Biol. Chem., 43, 771 (1979).

14) H. A. Lardy, D. Johnson and W. C. McMurray, Arch. Biochem. Biophys., 78, 587 (1958).

15) O. C. Tompson, B. Truelove and D. E. Davis, $J$. Agr. Food Chem., 17, 997 (1969). 